\title{
Science during the pandemic
}

Marilia Sá Carvalho 1

Luciana Dias de Lima 2

Cláudia Medina Coeli 3

doi: 10.1590/0102-311X00055520

Scientific journals play a key role in the strategies and actions to control the COVID-19 pandemic. The journals allow disseminating developments on a broad range of science issues.

Given the current situation's gravity, even paid journals are allowing free access to their articles. The Oswaldo Cruz Foundation (Fiocruz) has created a thematic platform to support research and measures related to the new coronavirus 1. Organized with an openaccess reference management software - Zotero -, as of March 22 the database contained some 1,600 papers, demonstrating the huge effort by the global scientific community.

All our editorial and publishing activities at CSP are being conducted remotely, and we intend to apply fast-track procedures to the review and publication of articles on COVID-19. But why maintain routine publication of other topics, apparently not as relevant at this stage of the crisis?

We are aware that although scientific studies are essential to back immediate decisions, Science has a significant impact on the future of societies, and that the production of scientific knowledge requires medium- and long-term investment by government and society. It is useless to demand urgency in vaccine development 2 if the conditions for such development have not been created in timely fashion. Besides, distrust towards vaccines' safety ${ }^{3}$, fueled by some government officials 4,5 , creates constraints that have to be dealt with in controlling and mitigating the epidemic's harms.

We are currently facing a long list of problems. The hope for diminishing the epidemic's impact on Brazil is based on accumulated knowledge. Various scientific journals in Brazil have published studies on the impact of primary healthcare (PHC) on the population's health 6, including scientists' inherent role of identifying the limits and conditions for improvement in the current context 7 . However, rather than improving the PHC proposal, there have been mass layoffs ${ }^{8}$. Scientists have also decried the underfinancing of all dimensions of the Brazilian Unified National Health System (SUS), including the impacts of a fiscal austerity policy that has cut essential budget funding from the social and health areas 9 .

The capacity of countries to respond depends on how their health systems are organized. Even in Italy, with a universal healthcare system (considered one of the best in Europe), hospitals have already reached the limit of their capacity to treat patients that require hospitalization and intensive care 10. While Spain has adopted mechanisms to nationalize
1 Programa de Computação Científica, Fundação Oswaldo Cruz, Rio de Janeiro, Brasil.

2 Escola Nacional de Saúde Pública Sergio Arouca, Fundação Oswaldo Cruz, Rio de Janeiro, Brasil. 3 Instituto de Estudos em Saúde Coletiva, Universidade Federal do Rio de Janeiro, Rio de Janeiro, Brasil. 
the private healthcare system ${ }^{11}$, Brazil is increasing the financing of private health plans 12 . The United Kingdom will maintain workers' salaries in order to avoid layoffs 13, while Brazilian companies have been authorized to cut the workday and wages 14 .

The fight against the epidemic must deal with the realities of countries with major socioeconomic inequality and different levels of disease burden. The previous health situation is not going to disappear simply because a new pathogen is spreading. The high prevalence of hypertension (one of the exacerbating factors in COVID-19 15), low socioeconomic status, and low schooling heavily influence the control of blood pressure levels and the outcome of the illness 16 . Social distancing is hardly feasible in low-income communities. Thus, besides inequality in care, the spread of COVID-19 will also be unequal.

A vision capable of predicting the directions taken by the coronavirus involves scientific methodology that incorporates information generated by hundreds of studies ${ }^{17}$. Air traffic data and data on movement within Brazil's states allows simulating the epidemic's spread and orienting resource allocation 18 .

Science publishing plays this crucial role, and the peer review system is a basic guarantee of high- quality research. This raises the discussion on "magic solutions", such as a recent article (whose reference we decline to cite) with 26 patients and a study design riddled with gross errors, concluding that hydroxychloroquine was associated with decreased viral load in COVID-19. Leaders of various countries, with no guarantee of efficacy whatsoever, immediately began to ignore basic safety rules and encourage the production and use of hydroxychloroquine for COVID-19. Meanwhile, they portrayed scientific rigor as a barrier to treatment 19 , even though the cure from such treatment is dubious and the adverse effects are severe.

The role of CSP is to publish honest, well-conducted scientific research, as illustrated by an article we published recently on the role of timely and effective health surveillance 20 . We intend to accelerate the review and publication of articles addressing various public health aspects to improve our understanding and handling of the current epidemic.

Scientists worldwide will certainly generate the knowledge that will allow us not only to deal with the COVID-19 pandemic, but also to back policies for adequate organization of patient care. We intend to contribute to the mitigation of the pandemic's harms, while looking to the future. After all, treating the infection's severity also involves treating hypertension 21.

\section{Contributors}

M. S. Carvalho, L. D. Lima, and C. M. Coeli contributed to the writing and approved the final version.

\section{Additional informations}

ORCID: Marilia Sá Carvalho (0000-0002-95660284); Luciana Dias de Lima (0000-0002-06408387); Cláudia Medina Coeli (0000-0003-17573940). 
1. Zotero. Novo coronavírus Covid-19 - Fiocruz. https://www.zotero.org/groups/2442236/no vo_coronavrus_covid-19__fiocruz (accessed on 22/Mar/2020).

2. Thorp HH. Do us a favor. Science 2020; 367: 1169.

3. Black S, Rappuoli R. A crisis of public confidence in vaccines. Sci Transl Med 2010; 2:61 mr1.

4. Hoffman J. President Trump on vaccines: from skeptic to cheerleader. The New York Times 2020; 9 mar. https://www.nytimes. com/2020/03/09/health/trump-vaccines. html.

5. Partido dos Trabalhadores. Bolsonaro corta quase R\$ 1 bilhão em vacinas do SUS, denuncia Padilha. https://pt.org.br/bolsonaro-corta -r-1-bilhao-em-vacinas-do-sus-denuncia-ale xandre-padilha/ (accessed on 20/Mar/2020).

6. Boing AF, Vicenzi RB, Magajewski F, Boing AC, Moretti-Pires RO, Peres KG, et al. Redução das internações por condições sensíveis à atenção primária no Brasil entre 1998-2009. Rev Saúde Pública 2012; 46:359-66.

7. Reis V. Contribuição da Rede APS ao debate sobre as recentes mudanças na política de Atenção Primária. https://www.abrasco.org. $\mathrm{br} /$ site/eventos/congresso-brasileiro-de-cien cias-sociais-e-humanas-em-saude/contribui cao-dos-pesquisadores-da-rede-aps-ao-deba te-sobre-as-recentes-mudancas-na-politicade-atencao-primaria/43125/ (accessed on 22/ Mar/2020).

8. Tchao E. Prefeitura do Rio começa a demitir funcionários do programa Clínica da Família. G1 2019; 17 jan. https://g1.globo.com/rj/riode-janeiro/noticia/2019/01/17/prefeitura-do -rio-comeca-a-demitir-funcionarios-do-pro grama-clinica-da-familia.ghtml.

9. Paes-Sousa R, Schramm JMA, Mendes LVP. Fiscal austerity and the health sector: the cost of adjustments. Ciênc Saúde Colet 2019; 24:4375-84.

10. Horowitz J. Italy's health care system groans under coronavirus - a warning to the world. The New York Times 2020; 12 mar. https:// www.nytimes.com/2020/03/12/world/ europe/12italy-coronavirus-health-care.html.

11. Democracy Now! Spain Locks down \& na tionalizes private healthcare as coronavirus deaths double \& cases skyrocket. https://www. democracynow.org/2020/3/17/spain_corona virus (accessed on 20/Mar/2020).

12. Linder J. Para evitar sobrecarga do sistema, governo vai facilitar liberação de R\$ 10 bi a planos de saúde. Estadão 2020; 19 mar. https:// saude.estadao.com.br/noticias/geral,para-e vitar-sobrecarga-do-sistema-governo-vai-fa cilitar-liberacao-de-r-10-bi-planos-de-sau de,70003240621.
13. Oswald V. Em medida "sem precedentes", Reino Unido vai pagar salários de trabalhadores para evitar demissões. O Globo 2020; 20 mar. https://oglobo.globo.com/economia/em-me dida-sem-precedentes-reino-unido-vai-pagarsalarios-de-trabalhadores-para-evitar-demis soes-24318385.

14. Pupo F, Resende T, Caram B. Governo vai permitir que empresas cortem jornada e salários pela metade devido ao coronavírus. Folha de S.Paulo 2020; 18 mar. https://www1.folha.uol. com.br/mercado/2020/03/governo-vai-per mitir-que-empresas-cortem-jornada-e-sala rios-pela-metade-por-conta-da-crise-do-co ronavirus.shtml.

15. Fang L, Karakiulakis G, Roth M. Are patients with hypertension and diabetes mellitus at increased risk for COVID-19 infection? Lancet Resp Med 2020; Online First. https://www. thelancet.com/journals/lanres/article/PIIS 2213-2600(20)30116-8/fulltext.

16. Chor D, Pinho Ribeiro AL, Sá Carvalho M, Duncan BB, Andrade Lotufo P, Araújo Nobre A, et al. Prevalence, awareness, treatment and influence of socioeconomic variables on control of high blood pressure: results of the ELSA-Brasil Study. PLoS One 2015; 10:e0127382.

17. Lana RM, Gomes MFC, Lima TFM, Honório NA, Codeço CT. The introduction of dengue follows transportation infrastructure changes in the state of Acre, Brazil: a networkbased analysis. PLoS Negl Trop Dis 2017; 11:e0006070.

18. Zorzetto R. Cidades à sombra do coronavírus. Pesquisa Fapesp 2020; 21 mar. https://revis tapesquisa.fapesp.br/2020/03/21/cidades-asombra-do-coronavirus/.

19. Correia L. Hidroxicloroquina: o dia em que a ciência parou. http://medicinabaseadaemevi dencias.blogspot.com/2020/03/hidroxicloro quina-o-dia-em-que-ciencia.html (accessed on 22/Mar/2020).

20. Lana RM, Coelho FC, Gomes MFC, Cruz OG, Bastos LS, Villela DAM, et al. The novel coronavirus (SARS-CoV-2) emergency and the role of timely and effective national health surveillance. Cad Saúde Pública 2020; 36:e00019620.

21. Minter A. To treat pandemics, start by treating hypertension. Bloomberg 2020; 19 mar. https://www.bloomberg.com/opinion/arti cles/2020-03-19/high-blood-pressure-is-riskfor-countries-after-coronavirus-ends. 